\title{
Personality Types and Persistence in Doctoral Students: A Mixed-Methods Study
}

\author{
Anique Falconer* and Sue Adragna \\ ${ }^{1}$ Department of psychology, Keiser University, USA \\ ${ }^{2}$ Department- Education
}

Submission: March 20, 2017; Published: March 31, 2017

*Corresponding author: AniqueFalconer, Department of psychology, Email: falconeranique@gmail.com

\begin{abstract}
High attrition rates exist in doctoral programs. The purposes of the current mixed-methods sequential explanatory study were to examine the relationship between doctoral student personality types and persistence and to explore doctoral students' perceptions of the impact of personality types on their persistence. Guided by the theoretical framework of retention and educational psychology theories, the current study was an examination of personality types and doctoral students. The overarching research questions were used to determine whether a significant correlation existed between doctoral students' personality types and their persistence, and to determine how doctoral students' perceptions of personality types influenced their academic persistence.
\end{abstract}

A mixed methods sequential explanatory study was conducted using the correlation and multiple case study designs. In the first phase, 47 participants completed the college persistence questionnaire and the 5 -factor model. In the second phase, 11 participants were involved in semi structured interviews. The cross-tabulation with associated chi-square, independent samples t test, and analysis of variance were the statistical tests used. The thematic analysis was used to uncover themes from the interviews. Results indicated a statistically significant relationship between neuroticism and persistence. Within-case analysis showed themes of extroversion and conscientiousness. Cross-case analysis themes included cognitive load, finances, faculty, and support.

Keywords: Doctoral student retention; Personality types; Academic persistence; Faculty support; Cognitive load; Finance and academic persistence

Abbreviations: SPS: Statistical Package for Social Sciences; ANOVA: Analysis of Variance; EI: Emotional Intelligence

\section{Introduction}

In the United States, the issue of student retention has spanned three decades [1], but despite the problem of retaining students across all educational levels, educational leaders have focused exclusively on the undergraduate student population [2]. The lack of studies focusing on graduate students is problematic because approximately 33\% to $70 \%$ of doctoral students drop out of their academic programs [3-6]. Although this problem exists across all disciplines, attrition rates in graduate education major's range from $50 \%$ to $70 \%[4,7]$. Due to the complexity of the problem, researchers have used a plethora of approaches to investigate student retention.

Summerskill's [8] theory represents one of the first ideas on student retention. Summerskill's [8] theory of student retention suggested that students' personality attributes influenced their decisions to remain or withdraw from their academic programs. Despite this critical finding, most researchers on student retention have investigated other variables, such as academic and student involvement [9,10], organizational attributes [11], environmental factors affecting nontraditional students [12], and college sizes $[13,14]$.

The need exists to address the gap in research on personality types and doctoral student retention because of the high attrition rates in doctoral students [15]. Moreover, many researchers have failed to investigate personality types as a casual factor of student attrition. The few studies, which have considered personality types as a casual factor in student retention, such as 
Felder, Felder, \& Dietz's [16] and Munt \& Merydith's [17], have targeted the undergraduate population. Since adult learners learn in different ways than their non-adult counterparts do [18], researchers cannot generalize the findings of these younger learners to doctoral students.

The essential empirical foundation for understanding adult learners dates back to Knowles's [18]. Knowles's [18] theory of andragogy- the way in which adults learn--included the assumptions that adult learners are self-directed, experienced, developmental, and problem-centered. A study conducted by Wilson [19] suggested that andragogy affects student satisfaction in non-traditional learning environments but does not affect learning. In other words, andragogy closely relates to affective factors but not cognitive factors. Affective factors are emotional factors, which affect student learning. Because personality types closely relate to how people manage and harness their emotions, a need exists to investigate the relationship between personality types and adult learners, such as doctoral students.

\section{Student Retention and Personality}

Personality psychologists have created several models used to understand and explain personality types [20-22]. One such model of personality is the Five Factor Model, which became a central theme in the 1990s [23]. The dimensions of the Five Factor Model include (a) conscientiousness, (b) neuroticism, (c) extraversion, (d) openness to experience, and (e) agreeableness [22]. Researchers who have investigated conscientious students found that conscientious students were high achievers who earned good grades [24-26].

In contrast, students who scored high in neuroticism and extraversion struggled academically [27-29]. Researchers have found disparate findings on the academic performance of students scoring high in openness to experience and agreeableness [30-34]. Researchers on academic performance and personality types are important because academic performance predicts student retention. It is however, necessary to examine how doctoral students' demographics have shifted over the past four decades to understand better how the current demographics relate to personality.

\section{Doctoral Students Demographics}

Since the 1960s, a shift has occurred in the doctoral student demographics; the differences involved the students' purposes for pursuing degrees, program involvement, and funding $[35,36]$. Doctoral students were predominantly Caucasian males who studied full-time [37]. Modern doctoral students include more minorities and females, who study part-time [36]. Approximately $12 \%$ of all doctoral students pursue their degree part-time at some point throughout their academic program [7]. Students enrolled part-time often lack the opportunity to participate in school activities. A lack of school involvement, in turn, leads to less satisfaction with the doctoral program $[7,15]$. Doctoral students enrolled part-time often experience challenges based on issues with balancing work life with school life. The challenges often manifest in negative emotions, such as isolation, which can affect student drive to complete the program [38,39].

\section{Understanding Attrition and Persistence in Doctoral Students}

The phenomenon of doctoral students' persistence is paradoxical given that institutional leaders enforce high academic standards for doctoral students, who are highly selected, yet doctoral students are the most likely to give up during their studies [3-6,40]. The attrition rates of doctoral students range from $33 \%$ to $70 \%$, and the primary contributors to attrition are stress, isolation, and personality $[15,28,41,42]$. Although researches on doctoral students are new, the issues are growing quickly [43]. Therefore, to ensure the success of doctoral students, education leaders must have a greater understanding of student persistence.

The high attrition rates are problematic because doctoral students (a) often contribute to the teaching and research of many universities [44], (b) have the role of research scholars and research assistants [45], and (c) experience financial losses and emotional consequences when they leave the program before completion $[46,47]$. Another implication involves the idea that faculty members receive training and development from doctoral study programs [48]; therefore, high attrition rates will lead to a shortage in the academic fields. Although the preceding points aids in the understanding of student persistence, many other factors contribute to an understanding of this complex issue.

\section{The Reasons Why Doctoral Students Remain in the Program}

A plethora of reasons affect a student's decision to persist [15], and researchers often categorize these reasons into student-related factors and institutional-related factors $[49,50]$. Student-related factors closely related to the self, and the factors influenced the students' decisions to remain in the program. Some of the variables included (a) demographic, (b) responsibility, and (c) personal attributes $[47,50]$. Conversely, institutional factors referred to the students' perceptions of the program-structure, curriculum, involvement, and faculty members $[49,51,52]$. Because past researchers have focused on the preceding variables, it is necessary to consider other factors - self-regulation and motivation.

\section{Other Factors Affecting Student Persistence: Self- Regulation and Motivation}

In an educational capacity, motivation refers to the processes in sustaining students to pursue and persist through an academic program [53]. Self-regulation comes into play when motivation towards meeting a goal (i.e. earning a degree) encounters 
difficulties [54]. Although self-regulation and motivation share commonalities, they differ in the dimension of choice. Thus, the use of effective self-regulated strategies could support students who encounter problems [54]. Students who lack self-regulated skills may experience issues with emotional intelligence, anxiety, and academic self-confidence [55]. Motivational factors could manifest in the form of (a) internal, (b) external, (c) locus of control, and (d) commitment to the school.

Motivation comes in the form of internal or external [56], and researchers have found internal motivation to be more influential in adult learning [57]. Although internal motivation is more beneficial for adult learning, learners need extrinsic motivation to sustain behaviors over long periods, and they need intrinsic motivation to strengthen and preserve learning [58]. Overexposure to extrinsic motivation can lead to counterproductive results [58], and lack of internal motivation calls for external motivation [59]. Thus, adult learners should balance the two motivations to earn the desired outcome.

Psychologists use the concept of locus of control, as a personality trait, to explain the extent to which people feel they have control over their behaviors [60]. Students with an internal locus of control feel their academic performance is dependent on their actions and choices [61]. In contrast, students with an external locus of control attribute their academic success to chance or luck [61]. In essence, the extents to which people feel they have control over their behaviors influences their academic success and persistence [60]. The way in which students attribute their success or failure influences their commitment. For example, Schunk and Zimmerman [62] proposed that students are more likely to persist when they attribute causal factors as internal, stable, and controllable.

Emotional intelligence refers to a person's ability to identify and manage the emotions themselves and the emotions of others [63]. Emotional Intelligence consists of four basic domains: selfawareness, social awareness, relationship management, and self-regulation. The latter plays an important part in student learning and success, which are both predictors of student persistence [64]. Self-regulated learners have control over their learning environments; hence, allowing these learners to control their efforts on academic tasks [65-67]. Therefore, the emotions of these learners could impede or motivate learning [68]. Learners who are unable to control their emotions could experience anxiety [69] and typically, people uses escape or avoidance behaviors to create a reduction in fear and anxiety [70]. Therefore, anxiety caused by academic stress and psychological issues could cause students to drop out [71]. Adult learners who have a strong academic self-confidence will experience less negative emotions, such as anxiety, and develop the strong identity needed to persist and become scholars within the field [72].

\section{Conclusion}

The issues of student retention in doctoral students have been a growing concern and very often researchers do not consider the doctoral student population or the relationship between personality types and student retention. The purposes of this mixed-methods study were to examine the relationship between doctoral student's personality type and persistence and explore doctoral students' perceptions of the impact of personality types on their persistence.

\section{Material and Methods}

A mixed methods sequential explanatory study was conducted, using the correlational design and the multiple case study designs.

\section{Sample}

Participants in the current study were of legal age and included doctoral students currently enrolled in doctoral programs, doctoral candidates, doctoral graduates, students who dropped out, and students whom school officials dismissed based on their poor academic standing. The sample consisted of 47 participants in the quantitative strand and 11 participants in the qualitative strand. Participants of the study were members of one of the following races: African American, Caucasian, Hispanic, Asian, Pacific Islander, or other. Participants in the quantitative strand were not asked their ages, but the age of participants in the qualitative strand ranged between 27 and 51, with an average age of 41 .

\section{Quantitative research questions}

The quantitative research questions in the current study were as follows:

Is there a significant correlation between doctoral students' personality type and persistence?

\section{Sub questions included:}

I. Is there a significant correlation between doctoral student's openness to experience and their persistence?

II. Is there a significant correlation between doctoral student's conscientiousness and their persistence?

III. Is there a significant correlation between doctoral student's extraversion and their persistence?

IV. Is there a significant correlation between doctoral student's agreeableness and their persistence?

V. Is there a significant correlation between doctoral student's neuroticism and their persistence?

\section{Qualitative research questions}

The qualitative research questions for the current study were as follows: 
How do doctoral students' perceptions of personality types influence their academic persistence?

\section{Sub questions included:}

I. How do doctoral students describe their personality types?

II. How do doctoral students describe their academic persistence?

III. What are doctoral students' perceptions of the influence that personality types have on their academic persistence?

\section{Procedure}

The convenience sampling method was used for the quantitative and qualitative strands, and the snowball sampling was used in the qualitative. In the quantitative phase, participants received the links to the study from Survey Monkey ${ }^{\circledR}$ via LinkedIn ${ }^{\circledR}$ and Facebook ${ }^{\circledR}$. Additionally, the links to the study had a letter that accompanied, which was used to detail the nature and risks of the study. One hundred and seventy participants completed either the Five-Factor Model or College Persistence Questionnaire Instruments. However, after cleaning both instruments by the IP addresses, only 47 participants completed both instruments, so the final data set consisted of 47 participants. A question was included on the study links from Survey Monkey®, which asked participants to provide their contact information to complete the second part of the studythe qualitative strand.

Participants in the qualitative strand were selected based on their educational level-doctoral students, graduates, candidates, and drops. Most of the participants were doctoral graduates; so many graduates had to be denied to ensure proportionate groups in each category. The final groups were three doctoral graduates, three doctoral students, three doctoral candidates, and two doctoral drops. The plan in the initial research proposal involved including three participants from each group (doctoral drops, doctoral candidates, doctoral students, and doctoral graduates) to ensure triangulation. After weeks of gathering data, only two participants who were doctoral dropouts were found who wanted to participate. The 11 participants took part in semi-structured interviews via phone calls. The phone calls were recorded after receiving permission from the participants.

In the quantitative strand, The Statistical Package for Social Sciences ${ }^{\circledR}$ (SPSS) computed the statistical tests. Crosstabulation was used to analyze the categorical data (i.e., personality types and persistence). The chi-square was used to determine whether the results from the cross-tabulation were statistically significant. An independent samples t-test compared the means of two personality types on the mean persistency. Analysis of variance (ANOVA) measured the differences among the personality types.

In the qualitative strand, the multiple case study was used, the within case followed by the cross-case analysis. The thematic analysis was used to narrow down a vast amount of information into patterns or themes. After data had been collected, the material was read and reread to create familiarity with the data and to search for themes and patterns. The next step involved using a Word $\AA$ Cloud tool to produce the initial codes. After that, the initial themes were sorted into main themes and subthemes, with the remainder discarded. The latter stages involved reviewing the themes, naming the themes, and writing the report. The themes were analyzed with each case and across all cases.

\section{Theory}

The study related the theoretical framework of retention and educational psychology theories, specifically,
a. Knowles's adult learning theory (andragogy),
b. the big five personality theory,
c. Summerskill theory of retention,
d. Vygotsky social learning theory, and
e. Bandura social cognitive theory.

The theoretical framework was used to focus on retention from a psychological standpoint. Knowles (1984) explained that adults learn in different ways compared to children and adolescents. Given that the sample population included doctoral students who were over the age of 18 , it was appropriate to view how andragogy interplayed with the study population. Considering the complexity of the Big Five Personality Model, it was necessary to see the behavioral themes, which emerged across the five dimensions. Summerskill [69] explained that students' personalities influenced their decisions to remain in the program or to leave the program. Vygotsky's [73] theory of social learning indicated that human social interactions have a role in cognitive development. Thus, students' relationships with their peers and teachers influence their ability to perform in the classroom. The Bandura social cognitive theory posits that behaviors are what individuals learn through internal motivation [74].

\section{Results: Quantitative Data}

The quantitative results will be presented first, followed by the qualitative results.

\section{ANOVA}

The analysis of variance (ANOVA) was used to analyze the differences in means among multiple personality types. Since the study was comprised of nominal data, a nonparametric analysis was used instead of parametric analysis. ANOVA showed the observed power of 0.484 , which was not very strong. The partial eta squared shows a weak effect of traits to the average scores of persistency. Results are shown in Table 1. 


\section{Psychology and Behavioral Science International Journal}

Table 1: ANOVA Testing the Effects of Traits on Persistency.

\begin{tabular}{|c|c|c|c|c|c|c|c|c|}
\hline & $\begin{array}{l}\text { Type III Sum } \\
\text { of Squares }\end{array}$ & Df & Mean & $\mathbf{F}$ & Sig. & $\begin{array}{l}\text { Partial Eta } \\
\text { Squared }\end{array}$ & $\begin{array}{l}\text { Noncent. } \\
\text { Parameter }\end{array}$ & ObservedPower $^{\mathrm{b}}$ \\
\hline $\begin{array}{c}\text { Corrected } \\
\text { Model }\end{array}$ & $.557 \mathrm{a}$ & 4 & 0.139 & 1.732 & .161 & .142 & 6.927 & .484 \\
\hline Intercept & 490.187 & 1 & 490.187 & 6091.816 & .000 & .993 & 6091.816 & 1.000 \\
\hline Traits & .557 & 4 & 0.139 & 1.732 & .161 & .142 & 6.927 & .484 \\
\hline Error & 3.380 & 42 & 0.080 & & & & & \\
\hline Total & 598.336 & 47 & & & & & & \\
\hline Corrected & 3.937 & 46 & & & & & & \\
\hline \multicolumn{9}{|c|}{ a. $\mathrm{R}$ squared $=0.142($ Adjusted $\mathrm{R}$ squared $=0.060$ ) } \\
\hline
\end{tabular}

\section{Cross-Tabulation with Associated Chi-Square}

The cross-tabulation with associated chi-square test showed no statistically significant correlation between traits and persistency, but it showed a statistically significant effect

Table 2: Cross-Tabulation Chi-Square.

\begin{tabular}{|l|c|c|c|}
\hline \multirow{2}{*}{$\begin{array}{c}\text { Nominal by } \\
\text { Interval }\end{array}$} & \multirow{2}{*}{ Eta } & $\begin{array}{c}\text { Traits } \\
\text { Dependent }\end{array}$ & $\mathbf{0 . 7 5 1}$ \\
\cline { 3 - 4 } & & $\begin{array}{c}\text { Persistency } \\
\text { Dependent }\end{array}$ & 0.376 \\
\hline
\end{tabular}

\section{Independent Samplest Test}

An independent sample t test was used to measure the mean scores of two traits. After measuring all combinations of traits, differences in Traits 2 and 3 (neuroticism and conscientiousness) and Traits 2 and 4 (neuroticism and agreeableness) were significantly different. In other words, students who scored highest in neuroticism persisted. The basic descriptive graphing dot plot was used to support the findings. The chart indicated that Trait 2, neuroticism, had the highest persistency. The chart is shown in Figure1.

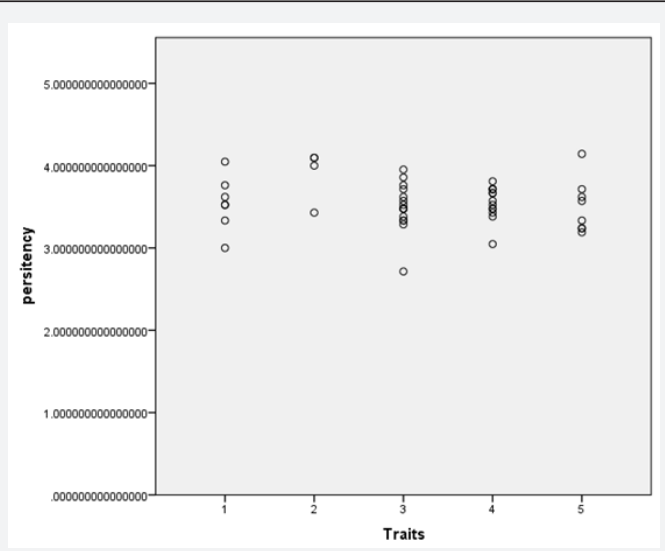

Figure 1: The chart indicating Trait 2, neuroticism, had the highest persistency. size (eta). The cross tabulation with associated chi-square that showed that persistency is traits dependent with an eta coefficient of 0.751 , which indicated a strong relationship. Results are shown in Table 2.

\section{Further Results by Research Questions}

The independent simplest test did not show a statistically significant relationship between four traits (openness to experience, conscientiousness, extraversion, and agreeableness) and the mean scores of all traits in relationship to persistency. However, the independent samples t test showed a statistically significant relationship between neuroticism and the mean scores of all traits in relationship to persistency. Students who scored highest in neuroticism persisted.

\section{Results: Qualitative Data}

The results of the within case analysis, followed by the crosscase analysis are reported below.

\section{Within Case Analysis}

Doctoral Candidates: The group of doctoral candidates rated their personalities highest in conscientiousness and on both ends of the extraversion scale. They also described their academic persistence as strong and explained that their upbringing influenced most their academic persistence. With regards to their personality, candidates explained that their strong sense of self and independence helped them to persist academically.

Doctoral Graduates: Doctoral graduates rated themselves low in extraversion and high in conscientiousness. When asked to describe their academic persistence, doctoral graduates related their responses to self-determination and family. Doctoral graduates explained that self-control was the most important factor in academic persistence.

Doctoral Students: Doctoral students highlighted dominance in the personality traits of conscientiousness, 
extraversion, and agreeableness. Participants explained that their academic persistence was strong because they wanted a better quality of life. Participants further explained that their self-motivation caused them to persist through the program.

\section{Doctoral Drops}

Doctoral drops scored low in agreeableness and on both ends of the extraversion scale. Participants indicated that they exhibited high conscientiousness for the duration of the program, but funding affected their decisions to remain in the program. Participants reported that their positive attitudes influenced their discipline, which in turn influenced their academic persistence.

\section{Cross Case-Analysis (Other Themes)}

Personality Types: The qualitative results supported that the personality traits of conscientiousness and extraversion relate to academic persistence in doctoral students. Most participants rated themselves high in conscientiousness. For instance, Graduate B said: "I have a very strong work ethic." Equivocal findings existed on the personality traits of extraversion; some participants rated themselves high in extroversion, while others scored low. Drop B: "I am more like a introvert, I like to keep things in." Candidate C said: "I would say I am outgoing. I get along well with people when I need to."

Cognitive Load: More than one-third of the participants interviewed highlighted cognitive load as a factor that affected their academic persistence. Participants expressed challenges with balancing the demands of school and their personal lives. For example, Drop A said: “"The course load was rigorous." Student B further explained: "I would say the course load compared to my master's and bachelor's ... is probably like ten times as much."

Finances: Almost half of the participants mentioned concerns with funding for the program or the cost of the program. The theme of finance was especially dominant for the two doctoral students who dropped out of the program. Drop A explained: "I would have wanted to have in writing the guarantee that I would receive compensation from the school to pay for the program." Drop B stated: "I just wish that I didn't take out loans and run out."

Dissertation Chairs, Committee, Professors: More than half of the participants highlighted the role of their dissertation chair, committee members, and professors in their academic persistence. Participants had negative and positive experiences working with these faculty members. Candidate B said: “... same with my dissertation chair. The same thing-they provided the tools and really fostered my independence throughout this degree." Conversely, Graduate A said: "Getting a hold of my dissertation chair in a timely manner and getting the feedback I need in order to finish that was the biggest challenge."

Institutional and Peer Support: Approximately45\%of participants expressed the importance of institutional and peer support in their academic persistence. Here is Student A's response relating to institutional support: "They introduced me to something I had not heard or seen more. They taught me about servant leadership. That helped megrow as a person."Candidate $\mathrm{C}$ added: "You were pretty much on your own. There was no coddling you. If you are not disciplined you are not going to make it through."

\section{Discussion}

The quantitative analysis revealed a statistically significant relationship between high scores of neuroticism and academic persistence in doctoral students. Although the trait of conscientiousness was not statistically significant, it ranked second in relationship to academic persistence. In the qualitative analysis, namely, the within case analysis, participants described themes highest in conscientiousness, and on both ends of the extraversion scale, indicating that some were introverted and others extraverted. In the across case analysis, again the themes of conscientiousness, and extraversion emerged. Other themes included cognitive load, finances, and dissertation chairs, committee, and professors.

It was unexpected to identify a statistically significant relationship between neuroticism, a negative trait, and academic persistence. Interestingly, participants provided responses in the qualitative analysis that aligned closely to neuroticism, but during the interviews, many did not describe themselves as neurotic. The unexpected result of neuroticism could be because of counterfactual thinking. In other words, missed opportunities or negative feeling that surface from missed opportunities will often trigger future positive behaviors. Another reason participant may not have rated themselves high in neuroticismor in some cases rate themselves at all-could be based on the embarrassment of describing themselves in a negative light. This idea supports Roger's [75] Concept of the Self, which suggested that discrepancies exit between a person's self-perception and the ideal self. Another idea relates to the relationship between neuroticism and Emotional Intelligence (EI). Research to support the findings indicated a significantly negative relationship exists between EI and neuroticism [76]; therefore, students who lack EI will not have an accurate understanding of their emotions.

The limitations of the study involved the amount of participants and the survey questions. It would have been beneficial to have a larger sample, but many participants did not complete both instruments. Linking both surveys would have allowed the 170 participants to complete all the information instead of completing one of the instruments. In retrospect, asking demographic information on the quantitative surveys could have yielded more data. Results from both the quantitative and qualitative sections of the current study indicated that academic persistence is trait-dependent; there is a strong relationship between some personality types and academic persistence. When asked to describe their personality, participants in the study often asked for an example, or they 
described their personalities in terms of Type A or Type B. Presumably, the lack of awareness of personality types also existed at an administrative level in higher-level institutions. Therefore, the result of the study can benefit high education leaders, doctoral students, and those who offer psychological services.

Recommendations for future practice include (a) providing psychological support for students and faculty, (b) require program chairs and committee members to provide doctoral students with feedback in a required time, (c) implement peer mentoring programs, (d) provide more financial assistantship programs for graduate students, and (e) provide an Introductory Life Skills Course, which teaches emotional management. Recommendation for future research includes the investigation of (a) the role of the cognitive load theory in doctoral student education, (b) neuroticism and academic persistence in doctoral students, and (c) Emotional intelligence as a predictor of academic persistence.

\section{Conclusion}

The purposes of the current mixed-methods sequential explanatory study were to examine the relationship between doctoral student's personality type and persistence and to explore doctoral students' perceptions of the impact of personality types on their persistence. The main aims of the study were to draw awareness to the high attrition rates in doctoral programs and to recommend ways of reducing the high attrition rates in doctoral students. Themes that emerged included the personality traits of extraversion, conscientiousness, and neuroticism. Other themes included cognitive load, finances, faculty, and support.

\section{References}

1. Seidman A (2012) College student retention: Formula for student success. Rowman \& Littlefield, Lanham, USA.

2. St. John EP, Daun-Barnett N, Moronski-Chapman KM (2012) Public policy and higher education: Reframing strategies for preparation, access, and college success. Routledge, New York, USA.

3. Gardner SK, Gopaul B (2012) The part-time doctoral student experience. International Journal of Doctoral Studies 7: 63-78.

4. Ivankova NV, Stick SL (2007) Students' persistence in a distributed doctoral program in educational leadership in higher education: A mixed-methods study. Research in Higher Education 48(1): 93-135.

5. Jiranek V (2010) Potential predictors of timely completion among dissertation research students at an Australian faculty of sciences. International Journal of Doctoral Studies 5: 1-13.

6. Kim D, Otts C (2010) The effect of loans on time to doctorate degree: Differences by race/ethnicity, field of study, and institutional characteristics. Journal of Higher Education 81(1): 1-32.

7. Nettles MT, Millett CM (2006) Three magic letters: Getting to Ph.D, John Hopkins University Press, Baltimore, USA.

8. Summerskill J (1962) The American College. Wiley, New York, USA.

9. Astin AW (1977) Four critical years. Jossey-Bass, San Francisco, USA.

10. Tinto V (1975) Dropouts from higher education: a theoretical synthesis of recent research. Review of Educational Research 45(1): 89-125.
11. Bean J (1980) Dropouts and turnover: The synthesis and test of a casual model of student attrition. Research in Higher Education 12(2): 155-187.

12. Bean JP, Metzner BS (1985) A conceptual model of nontraditional student attrition. Review of Educational Research 55: 485-540.

13. Kamens DH (1971) The college "charter" and college size: Effects on occupational choice and college attrition. Sociology of Education 44(3): 270-296.

14. Kamens DH (1974) Colleges and elite formation: The case of prestigious American colleges. Sociology of Education 47(3): 354-378.

15. Gardner SK (2008) Fitting the mold of graduate school: A qualitative study of socialization in doctoral education. Innovative Higher Education: 33(2): 125-138.

16. Felder RM, Felder GN, Dietz EJ (2002) The effects of personality type on engineering student performance and attitudes. Journal of Engineering Education 91(1): 3-17.

17. Munt JA, Merydith SP (2012) The relationship of students' personality traits and psychosocial characteristics with academic retention. Journal of College Student Retention: Research, Theory, and Practice 13(4): 457-478.

18. Knowles MS (1984) Andragogy in action: Applying modern principles of adult learning. Wiley, New York, USA.

19. Wilson LS (2005) A test of andragogy in a post-secondary educational setting. Unpublished dissertation. Louisiana State University and Agricultural and Mechanical College, USA.

20. Allport GW (1937) Personality: A psychological interpretation. H. Holt and Company, New York, USA.

21. Eysenck HJ (1992) Four ways five factors are not basic. Personality and Individual Differences 13(6): 667-673.

22. McCrae RR, Costa PT (1987) Validation of the five-factor model of personality across instruments and observers. J Pers Soc Psychol 52(1): 81-90.

23. Friedman HS, Schustack MW (2016) Personality: Classic theories and modern research ( $6^{\text {th }}$ edn.). Boston: Pearson, USA.

24. Conrad N, Patry MW (2012) Conscientiousness and academic performance: A mediational analysis. International Journal for the Scholarship of Teaching and Learning 6(1): 8.

25. Hakimi S, Hejazi E, Lavasani MG (2011) The relationships between personality traits and students' academic achievement. ProcediaSocial and Behavioral Sciences 29: 836-845.

26. Weiten W, Dunn D, Hammer E (2014) Psychology applied to modern life: Adjustment in the $21^{\text {st }}$ century $\left(11^{\text {th }}\right.$ edn.). Cengage Learning, Stamford, USA.

27. Chamorro-Premuzic T, Furnham A (2003) Personality predicts academic performance: Evidence from two longitudinal university samples. Journal of Research in Personality 37(4): 319-338.

28. Furnham A, Nuygards S, Chamorro-Premuzic T (2013) Personality, assessment methods, and academic performance. Instructional Science 41(5): 975-987.

29. Serdar T, Suleyman M (2009) Trait emotional intelligence, the Big Five personality dimensions and academic success in physical education teacher candidate. Social Behavior and Personality 37(7): 921-931.

30. Akomolafe MJ (2013) Personality characteristics as predictors of academic performance of secondary school students. Mediterranean Journal of Social Sciences 4(2): 657-664.

31. Chamorro-Premuzic T, Furnham A (2008) Personality, intelligence and approaches to learning as predictors of academic performance. Personality and Individual Differences 44(7): 1596-1603. 
32. O'Connor M, Paunonen S (2007) Big Five personality predictors of post-secondary academic performance. Personality and Individual Differences 43(5): 971-990.

33. Paunonen SV (1998) Hierarchical organization of personality and prediction of behavior. Journal of Personality and Social Psychology 74(2): 538-556.

34. Rothstein MG, Paunonen SV, Rush JC, King GA (1994) Personality and cognitive ability predictors of performance in graduate business school. Journal of Educational Psychology 86(4): 516-530.

35. Brus CP (2006) Seeking balance in graduate school: A realistic expectation or a dangerous dilemma? New Directions for Student Services 2006(115): 31-45.

36. Offerman M (2011) Profile of the nontraditional doctoral degree student. New Directions for Adult and Continuing Education 129: 2130.

37. Gardner SK (2009) The development of doctoral students: Phases of challenge and support. Jossey-Bass, San Francisco, USA.

38. Golde CM (2005) The role of the department and discipline in doctoral student attrition: Lessons from four departments. Journal of Higher Education 76(6): 669-700.

39. Nutov L, Hazzan O (2011) Feeling the doctorate: Is doctoral research that studies the emotional labour of doctoral students possible? International Journal of Doctoral Studies 6: 19-31.

40. Golde CM (2000) Should I stay or should I go? Student descriptions of the doctoral attrition process. Review of Higher Education 23(2): 199-227.

41. Ali A, Kohun F (2007) Dealing with social isolation to minimize doctoral attrition: A four stage framework. International Journal of Doctoral Studies 2: 33-49.

42. Barnes BJ (2010) The nature of exemplary doctoral advisors' expectations and the ways they may influence doctoral persistence. Journal of College Student Retention: Research, Theory and Practice, 11(3), 323-343.

43. Jones M (2013) Issues in doctoral studies - Forty Years of journal discussion: Where have we been and where are we going? International Journal of Doctoral Studies 8: 1-22.

44. Ampaw FD, Jaege AJ (2011) Completing the three stages of doctoral education: An event history analysis. Research Higher Education 53(6): 640-660.

45. Altbach P, Reisberg L, Yudkevich M, Androushchak G, Pacheco I (2012) Paying the professoriate: A global comparison of compensation and contracts. Routledge, New York, USA.

46. Gururaj S, Heilig JV, Somers P (2010) Graduate student persistence: Evidence from three decades. Journal of Student Financial Aid 40(1): 31-46.

47. Lovitts, B. E. (2001) Leaving the ivory tower: The causes and consequences of departure from doctoral study. Rowman \& Littlefield, Lanham, USA.

48. Davis H, Evans T, Hickey C (2006) A knowledge-based economy landscape: Implications for tertiary education and research training in Australia. Journal of Higher Education Policy and Management 28(3): 231-244.

49. Tinto V (1993) Leaving college: Rethinking the causes and cures of student attrition $\left(2^{\text {nd }}\right.$ edn). University of Chicago Press, Chicago, USA.

50. Wao HO, Onwuegbuzie AJ (2011) A mixed research investigation of factors related to time to the doctorate in education. International Journal of Doctoral Studies 6: 115-134.

51. Pascarella ET (1980) Student-faculty informal contact and college outcomes. Review of Educational Research 50: 545-595.
52. Pascarella ET, Terenzini PT (2005) How college affects students: (Vol. 2): A third decade of research. John Wiley \& Sons, San Francisco, USA.

53. Korb R (2012) Motivating defiant and disruptive students to learn: Positive classroom strategies. Corwin Press, Thousand Oaks, USA.

54. Oettingen G, Gollwitzer PM (2015) Self-Regulation in adolescence. Cambridge University Press, New York, USA.

55. Scarr S, McCartney K (1983) How people make their own environments. Child Dev 54(2): 424-435.

56. Deci E, Ryan RM (2014) Intrinsic motivation and self-determination in human behavior. Springer Science and Business Media, New York, USA

57. Knowles MS, Holton EF, Swanson RA (2014) The adult learner: The definitive classic in adult education and human resource development. Routledge, London, UK.

58. Sogunro OA (2015) Motivating factors for adult learners in higher education. International Journal of Higher Education 4(1): 22-37.

59. Ahl H (2006) Motivation in adult education: A problem solver or a euphemism for direction and control? International Journal of Lifelong Education 25(4): 385-405.

60. Lefcourt HM (2014) Locus of control: Current trends in theory and research $\left(2^{\text {nd }}\right.$ edn). Psychology Press, East Sussex, UK.

61. Wiseman DG, Hunt G (2014) Best practice of motivation and management in the classroom: An integrative approach. Springfield, Charles C. Thomas Publisher, USA.

62. Schunk DH, Zimmerman BJ (2006) Competence and control beliefs: Distinguishing the means and ends. In PA Alexander \& PH Winne (Eds.), Handbook of educational psychology $\left(2^{\text {nd }}\right.$ edn). Mahwah, Lawrence Erlbaum Associates, USA, pp. 349-367.

63. Ciarrochi J, Mayer JD (2013) Applying emotional intelligence: A practitioner's guide. Psychology Press, New York, USA.

64.Das N (2009) The influence of individual factors on web-based developmental education course success in a two-year technical college (Doctoral dissertation). University of New Orleans, New Orleans, USA.

65. Corno L (1986) The metacognitive control components of selfregulated learning.Contemporary Educational Psychology 11(4): 333346.

66. Corno L, Rohrkemper M (1985) The intrinsic motivation to learn in classrooms. In C Ames \& R Ames (Eds.), Research on motivation: (Vol 2). The classroom milieu. Academic Press, New York, USA, p. 53-90.

67. Pintrich PR (1995) Understanding self-regulated learning. New Directions for Teaching and Learning 63: 3-12.

68. Dirkx JM (2001) The power of feelings: Emotion, imagination, and the construction of meaning in adult learning. New Directions for Adult and Continuing Education 89: 63-72.

69. Hashempour S, Mehrad A (2014) The effect of anxiety and emotional intelligence on students' learning process. Journal of Education and Social Police 1(2): 115-122.

70. Pavlov IP (1897/1910) The work of the digestive glands. Griffin, London, UK.

71. Ratanasiripong P, Sverduk K, Hayashino D, Prince J (2010) Setting up the next generation biofeedback program for stress and anxiety management for college students: a simple and cost-effective approach. College Student Journal 44(1): 97-100.

72. Coffman K, Putman P, Adkisson A, Kriner B, Monaghan C (2016) Waiting for the expert to arrive: Using a community of practice to develop the scholarly identity of doctoral students. International Journal of Teaching and Learning in Higher Education 28(1): 30-37. 
73. Vygotsky LS (1978) Mind in society: The development of higher psychological processes. Harvard University Press, Cambridge, UK.

74. Bandura A (1986) Social foundations of thought and action: A social cognitive theory. Prentice-Hall, Englewood Cliffs, USA.
75. Rogers C (1951) Client-centered therapy: Its current practice, implications and theory. Constable, London, UK.

76. Atta M, Ather M, Bano M (2013) Emotional intelligence and personality traits among university teachers: Relationship and gender differences. International Journal of Business and Social Science 4(17): 253-259.

\section{Your next submission with JuniperPublishers} will reach you the below assets

- Quality Editorial service

- Swift Peer Review

- Reprints availability

- E-prints Service

- Manuscript Podcast for convenient understanding

- Global attainment for your research

- Manuscript accessibility in different formats ( Pdf, E-pub, Full Text, Audio)

- Unceasing customer service

Track the below URL for one-step submission https://juniperpublishers.com/online-submission.php 